\title{
Students' Attitudes toward Problem Based Learning - Analog Electronic Course in the Electrical Engineering Programs in PPU Case Study
}

\begin{abstract}
Abdallah M. Arman
Palestine Polytechnic University, Hebron, Palestine

armana@ppu.edu

Received date: 3 March 2016; Accepted date: 3 June 2018; Published date: 30 November 2018

Academic Editor: Marlita Mat Yusof

Copyright (C) 2018. Abdallah M. Arman. Distributed under Creative Commons CC-BY 4.0

Abstract

In Palestine, there is a growing recognition for innovative teaching and learning approaches such as Problem-Based Learning (PBL) in engineering education in order to develop competence graduates. According to Kitogo (2011), "today's graduates have attractive curricula vitae, but practically, their performance is insufficient; it doesn't match with what they claim to have studied". The researcher sees that people learn when being actively involved in constructing meaning. In other terms, successful learning requires individuals' active participation and involvement. PBL as a dynamic approach of teaching in which students explore real-world problems, issues and challenges, students are inspired to obtain a deeper knowledge of the subjects they are studying and more likely to retain the knowledge gained through this approach far more readily than through traditional textbook centered. This principle agrees with the Chinese saying "Tell me and I forget, show me and I remember, involve me and I learn".This article presents a survey about the usage and the attitudes toward education technology at PPU in Palestine. The survey aims at assessing the experience, skills and computer efficacy of students, measuring their attitudes towards the use of education technology and distinguishing obstacles for the development of a cooperative learning environment. The results indicate positive attitudes of students toward this new approach of learning. The survey is used for the development of the university teaching and learning strategies, providing information on how to establish systems and procedures that enable the effective use of a PBL approach.
\end{abstract}

Keywords: Project Based Learning, Features, Analog Electronics, Students' Attitude 


\section{Introduction}

No one can deny that advances in information technology coupled with the changes in society are creating new paradigms for education and training. These changes will affect our education and training systems. Participants in this educational and training paradigm require rich learning environment supported by well-designed resources (Khan, 1997). Therefore, there is a great demand for affordable, efficient, easily accessible, open, flexible, learner- centered and facilitated learning environment. One of the approaches which reflects the principles of learner- centeredness is Problem-Based Learning (PBL).The theoretical foundation of Problem-based learning is strongly grounded on constructivism. In this regard, Railsback (2002: 6) maintains that "Problem-based instruction strategies have their roots in the constructivist approach". Moreover, PBL borrows its principles from pragmatic constructivism, cognitive constructivism and social constructivism, which constitute the main stands of the constructivist learning theory. In other terms, it commonly includes the ideas of Dewey's philosophy, Piaget's cognitive theory, and Vygotsky's social constructivist theory.

I believe that since PBL is potentially Motivating, empowering and challenging to learners, it usually results in building learners' confidence, self-esteem, and autonomy as well as improving students' language skills, content learning, and cognitive abilities, so learning becomes fruitful for learners because they exhibit their abilities to plan, manage, and accomplish projects through their content knowledge and skills "Problem -based learning is an instructional method centered on the learner as assured by (Erdem, 2012; Harris \& Katz, 2001)". Instead of using a rigid lesson plan that directs a learner down a specific path of learning outcomes or objectives, projectbased learning allows in-depth investigation of a topic. "Problem-based learning is a comprehensive approach to classroom teaching and learning that is designed to engage students in investigation of complex, authentic problems and carefully designed products and tasks (Blumenfeld, et al. 1991; Demirhan, 2002).

Problem-based learning (PBL) is still in the developmental stage. There is not sufficient research or empirical data to be able to state with certainty that problem-based learning is a proven alternative to other forms of learning, especially in the Arab countries. Based on evidence gathered over the past years, problem-based learning appears to be an effective model for producing gains in academic achievement. However, only a few of them have focused on problem-based learning in Electrical Engineering. Analogue electronic components and circuits are building blocks for any electronic device used in industries or in daily life. It is therefore necessary for electronics engineers to understand clearly the principles and functioning of the basic analogue components and circuits. This course will enable the students to understand the basics of construction, working, and applications of various types of electronic components such as Diodes, BJT, JFET, MOSJFET and circuits such as Small Signal amplifier, oscillators, power amplifiers, operational amplifier, and timers using linear ICs. Practical exercises of this course would enable students to maintain such circuits and in turn maintain equipment having such circuits. This course is therefore one of the basic core courses which is a must for every electronic engineer and hence should be taken very sincerely by students.

The need for this study arises from three main things: the personal experience of the researcher in teaching field, the literature review on problem-based approach and the roles of the teacher and real needs of teachers of Electronics. First, the researcher noticed that students' achievement level in Electronics courses is decreasing as they practice learning Electronics almost only inside the class or to study for the exams. As a result, the researcher tried to find a useful strategy to facilitate learning Electronics. Second, having reviewed the current literature, the 
researcher has figured out that the field of Electronics teaching and learning is poor in studies concerning the roles of the teacher and learners in light of the problem-based learning approach to teaching Electronics in Arab countries. Third, the unexpected low rate of success in these courses is a problem which deserves to be studied.

Eagly and Chaiken (1993) define attitude as "a psychological tendency that is expressed by evaluating a particular entity with some degree of favor or disfavor". In problem-based learning (PBL) activities, students work in a group to solve challenging problems which are authentic; students create an end product through intellectual inquiry and involving meaningful tasks. Moreover, because project work activities address the different learning styles of students, Problem-based learning takes individual differences into consideration by giving students a chance to select their own topics (Wrigley, 1998).Therefore, PBL is not a new method and it has a connection with many old approaches as their contributions to concepts such as action-based learning, learning by doing, group dynamics and interpersonal communication have been instrumental in shaping many theories of learning and teaching, and when combined together, reveal the bare bones of PBL.

Student attitudes are considerably related to motivation and success. Having high skills and talents is not enough for students to complete a task successfully and to make them like an activity as they are doing it. In order to sustain students' motivation, a positive opinion about the learning task and an internal stimulus is needed. Attitudes and beliefs are accepted as the pioneers of behavioral objectives. The probability of having willingness about learning tasks and sustainability of efforts are higher in students with a positive attitude. According to Mattern and Schau (2002), a positive attitude toward science classes is directly proportional to success. Therefore, it is important to find answers to questions asking what can be done to increase student interest toward science classes and to turn science classrooms into more enjoyable places. This study also aims to identify the effect of PBL on the attitudes of 3rd-year undergraduate students toward Electronics.

\section{Problem -Based vs. Traditional Instruction}

PBL is generally less structured than traditional, teacher-led classroom activities; in a problem-based class, students often must organize their own work and manage their own time. Within the problem-based learning framework, students collaborate, working together to make sense of what is going on. Problembased instruction differs from inquirybased activity by its emphasis on collaborative learning. Additionally, Problem-based instruction differs from traditional inquiry by its emphasis on students' own artifact construction to represent what is being learned.

Both traditional and problem-based instruction may have the same course goals, objectives, and outcomes. Both have the same dilemma of getting students to learn the "need to know material" in a restricted time frame. Yet, there are several ways to distinguish between Traditional Instruction and PBL as tabulated in table 1: 
Table 1: Differences between Traditional Instruction and PBL

\begin{tabular}{|l|l|}
\hline \multicolumn{1}{|c|}{ PBL } & \multicolumn{1}{|c|}{ Traditional } \\
\hline $\begin{array}{l}\text { Student-centered, students help each other } \\
\text { and teacher just facilitates the learning } \\
\text { Problem based and independent learning }\end{array}$ & $\begin{array}{l}\text { Teacher-Centered and teacher responsible for } \\
\text { the learning } \\
\text { Problem solving and dependent learning }\end{array}$ \\
\hline $\begin{array}{l}\text { Constructing individual's knowledge through } \\
\text { searching solutions for real life problem }\end{array}$ & $\begin{array}{l}\text { Transmitting knowledge to a group through } \\
\text { lectures }\end{array}$ \\
\hline $\begin{array}{l}\text { Focusing on the understanding of content and } \\
\text { integrate previous knowledge }\end{array}$ & Focusing on memorization of material \\
\hline Deep and active Learning & Surface learning \\
\hline Group Learning & Individual learning \\
\hline Performance-based assessment & Traditional Assessment \\
\hline
\end{tabular}

\section{Advantages of Problem-Based Learning}

According to Westwood (2008: 34-35), the problem approach can be applied in almost all areas of the curriculum as it is useful because:

1- Projects have a 'real world' orientation and promote meaningful learning by connecting new information to students' past experiences and prior knowledge.

2- Students learn valuable processes and skills for gathering and analyzing data.

3- Students are responsible for their own learning, thus increasing selfdirection and motivation.

4- The learning process encourages various modes of communication and representation.

5- The approach encourages the use of higher-order thinking as well as acquisition of facts.

6- The approach develops deeper knowledge of subject matter.

7- The approach also increases teamworking and cooperative learning skills.

\section{Methodology}

Attitude is an internal state that influences student's choices or decisions to act under certain conditions. Attitudes represent a tendency to respond in a particular way. In order to find out the students' attitudes toward the PBL approach, I have designed a 30 term questionnaire has been designed. The questionnaire shown in appendix (1) contains terms concerning:

- Using Computer and Internet in Education

- $\quad$ Self Directed Learning

- $\quad$ Cooperative Learning Style

- Practical Skills in Electronics

The Likert technique was used. The technique presents a set of attitudes statements. Students are asked to express agreement or disagreement of a five-point scale. Each degree of agreement is given a numerical value from one to five. Thus a total numerical value can be calculated from all the responses i.e. the final score for the respondent on the scale is the sum of their ratings for all the items. In the case of reversal items, the scale will be reversed.

Also, the questionnaire includes data questions about gender and it includes information about ownership of PC and Internet access. 
To ensure content validity, the questionnaire was checked out by an expert in the field of education and for validity test, it was run on a group of students whose attitudes are known and the result is positive ensuring questionnaire validity.

\section{Analysis of Students' Attitudes toward PBL}

The analysis of terms for the attitudes of students toward PBL was carried out using the five-point Likert scale consisting of (1) strongly disagree, (2) disagree, (3) Neutral, (4) agree, (5) strongly agree, which was used in the items that measure attitudes. For statistical analysis, the descriptive procedures in SPSS (version 15) were used. The Cronbach's Alpha equals 0.731 which is suitable for the research. The results are shown in the tables in the appendix (2).

\section{Results}

\section{Computer Infrastructure}

From (Table 3), all students have access to a privately owned PC they can use for their studies.

\section{Internet Access}

From (Table 4), all students have access to the Internet via ADSL.

\section{Using Computer and Internet in Education}

From (Table 5), most of the students are familiar with office applications and they enjoy using computer daily to perform educational tasks, and most of them agree that computer should play more important roles in Engineering education (item2, with mean equals 3.42 and SD equals 0.9 ).

Also, from (Table 5), most of the students are familiar with e-mail, chat, and discussions. Most of the students can search the Internet for scientific information (item 5 with mean equals 4.42 and SD equals 0.669). From item 7 , it is clear that students are interested in computer simulation.

\section{Cooperative Learning Style}

From (Table 6), it is clear that most of the students prefer learning with friends and like working on projects in a group (item 8 with mean equals 4.17 and SD equals 0.718 ) and item 10 with mean equals 3.83 and SD equals 0.835 ). From (Table 6), most of the students prefer learning collaboratively with friends and enjoy discussing scientific projects with their classmates (item 11 with mean equals 4.08 and SD equals 0.669).

\section{Self Directed Learning}

An important part of PBL is Self Directed Learning. It has been described as a process in which students take the initiative with or without help of teachers to formulate learning goals and choosing resources for learning.

From (Table 7), most of the students agree that they can take the initiative to diagnose their learning needs (item 19 with mean equals 4.17 and SD equals 0.937), identify the resources to achieve required objects of learning, select and implement certain application by searching the manufacturer Data Sheet of electronic components (item 17 with mean equals 4.33 and SD equals 0.492).

\section{Practical Skills in Electronics}

From (Table 8), most of the students prefer practical work. They agree that practical skills in Electronics enrich their creativity (item 26 with mean equals 3.33 and SD equals 0.778), develop their self assessment (item 27 with mean equals 3.08 and SD equals 1.165), increase their sense of responsibility (item 25 with mean equals 4.00 and SD equals 0.853), and enhance their self-confidence as future engineers (item 30 with mean equals 4.00 and SD equals 0.603 ).

\section{Discussion and Conclusion}

The survey was very revealing of the attitudes of students for PBL and educational technologies. As can be seen from tables (5 up to 9), the overall mean for most of the items is greater than (3) on 
a five-point Likert scale, which means that the general student attitude toward PBL was quite positive. The Cronbach's Alpha was run and determined to be 0.731 (Table 1) which is acceptable for this research.

The need for PBL policies is today vital for our universities, because of the potential of educational technologies and the magnitude of changes they may provoke in education. The introduction and development of PBL require the involvement and collaboration of many different units within the university. The Institution should provide to students support and training in PBL, to enhance the positive attitudes. It should be clear that students have a key role in the success of any transformation in education and the attempt to introduce PBL practices into the curriculum will unquestionably fail unless students get persuaded for the benefits. Hybrid approach should be used in our universities.

\section{References}

1. Bethlehem,P.A. (1997). National Association of Colleges and Employers.JobOutlook98.

http://www.gamesover.org/new_career/tr ansferable_skills

2. Blumenfeld, P., et al. (1994). Lessons learned: How collaboration helped middle grade science teachers learn project-based instruction. The Elementary School Journal,94(5). 539-551. Retrieved Jan10, 2013

from:http://uhu.es/gaiainm/invest_escolar /httpdocs/biblioteca_pdf/2_AndersonR\%5 B1\%5D.D.(2002)Inquiry.pdf

3. Case, J. M. (2011). Knowledge matters: interrogating the curriculum debate in engineering. Journal of Education, 51,7392.

4. de Graaff, E., \& Kolmos, A. (2003). Characteristics of Problem-Based Learning. International Journal of Engineering Education, 19(5), 657-662.

5. Demirhan, C. (2002). The Difficulties Encountered in the Practice of Project- based Learning Method In Elementary Science Teaching Method and the Precautions that have to be taken. Unpublished Master's Thesis, Northern Michigan University. RetrievedJan14, 2013 from:

http://www.tojned.net/pdf/tojnedv01i0401.pdf

6. Dochy, F., Segers, M., Van den Bossche, P., \& Gijbels, D. (2003). Effects of ProblemBased Learning: A Meta-Analysis. Learning and Instruction, 13(5), 553-568

7. Eagly , A., Chaiken , S.(1993).The Psychology of Attitudes .Orland ,FL: Harcourt BraceJovanovich College Publishers.

8. Erasmus, B. J., Loedolff, P. v. Z., Mda, T. V., \& Nel, P. S. (2006). Managing training and development in South Africa (5 ed.). Southern Africa: Oxford University Press.

9. Erdem,E.(2012).Examination of the Effects of Project Based Learning Approach on Students' Attitudes Towards Chemistry and Test Anxiety. World Applied Sciences Journal,17 (6), 764-769. Retrieved Jan10, 2013 from:http://idosi.org/wasj/wasj17(6)12/1 5.pdf

10.Griesel, H., \& Parker, B. (2009). A baseline study on South African graduates from the perspective of employers Graduate Attributes. South Africa: Higher Education South Africa \& The South African Qualifications Authority. http://www.saqa.org.za/docs/pubs/gener al/graduate_attributes.pdf.

11.Harris, J. \& Katz ,L.(2001) .Young investigators: The project approach in the early years. New York : Teachers College Press. Retrieved Jan 20, 2013from: http://www.naeyc.org/files/yc/file/20080 7/BTJJudyHarrisHelm.pdf

12.Hedge, T. (2002). Teaching and Learning in the Language Classroom. Shanghai: Shanghai Foreign Language Education Press. 
13.Khan, B. (1997). Web-based instruction: What is it and why is it? In B. H. Khan (Ed.), Web-based instruction (pp.5-18). Englewood Cliffs, NJ: Educational Technology Publications.

14.Kitogo, A. S. (2011). How competent are Tanzanian graduates? Retrieved 28/11/2011,fromhttp://varsitycollegetz.ni ng.com/profiles/blogs/howcompetent-aretanzanian-graduates.

15.Kolmos, A., de Graaff, E., \& DU, X. (2009). Diversity of PBL - PBL Learning Principles and Modules. In X. DU, E. de Graaff \& A. Kolmos (Eds.), Research on PBL Practice in Engineering Education (pp. 9-21). Rotterdam: Sense Publishers.
16.Kolmos, A., Fink, K. F., \& Krogh, L. (2006). The Aalborg PBL model - Progress, Diversity and Challenges Vol. 1. (pp. 393). Retrieved from http://www.bogide.dk/productsamples/9788773079119.p df

17.Railsback ,2002 .Project - Based Instruction: Creating Excitement for Learning. North West Regional Education Laboratory . Retrieved on May 14,2013fromhttp://www.btc.uob:.edu.bh/ UltimateEditorInclude/UserFiles/TCPB\%2 0322Teaching).pdf

18. Whitehead, A., N. (1992). The Aims of Education and Other Essays. Rich environment for active learning in action: PBL .New York: Macmillan.

\section{Appendix}

\section{Results of the Questionnaire for Students' Attitudes toward PBL}

\begin{tabular}{|c|c|c|}
\hline Items & Mean & SD \\
\hline \multicolumn{3}{|l|}{ I. Using Computer and Internet in Education : } \\
\hline 1- I am interesting using office applications (like MS-Word, Excel). & 3.67 & .778 \\
\hline $\begin{array}{l}\text { 2- In Electrical Engineering, the computer should play more important } \\
\text { roles }\end{array}$ & 3.42 & .900 \\
\hline 3- I enjoy sending e-mail and I like chatting & 4.08 & .669 \\
\hline 4- I can search the internet for scientific information. & 3.83 & 1.267 \\
\hline 5- I believe that the internet will facilitate education & 4.42 & .669 \\
\hline 6- Using Multimedia facilitates the education of Engineering & 3.92 & .793 \\
\hline 7- I am interesting with computer simulation . & 3.50 & 1.446 \\
\hline \multicolumn{3}{|l|}{ II. Cooperative Learning Style : } \\
\hline 8- I prefer learning with peers in a group. & 4.17 & .718 \\
\hline 9- I don't prefer the individual study. & 3.08 & 1.084 \\
\hline 10- I enjoy discussing scientific projects with friends. & 3.83 & .835 \\
\hline $\begin{array}{l}\text { 11- It is interesting to work collaboratively with other students to finish } \\
\text { project work. }\end{array}$ & 4.08 & .669 \\
\hline
\end{tabular}




\begin{tabular}{|c|c|c|}
\hline 12- Studying with peers means time loosing. & 3.92 & .900 \\
\hline 13- I like to compute with others to solve a problem. & 4.33 & .651 \\
\hline 14- I like working on projects alone. & 2.83 & 1.467 \\
\hline \multicolumn{3}{|l|}{ III. Self Directed Learning : } \\
\hline 15- I can not select the topic in accordance with my interest. & 2.50 & 1.243 \\
\hline 16- I can find the appropriate resources to achieve required objects. & 4.08 & .669 \\
\hline $\begin{array}{l}\text { 17- I can search the manufacturer Data Sheet of electronic components } \\
\text { easily }\end{array}$ & 4.33 & .492 \\
\hline 18- I can't learn without help of my facilitator at all. & 3.42 & .996 \\
\hline 19- I can learn new subjects by myself.. & 4.17 & .937 \\
\hline $\begin{array}{l}\text { 20- I can easily ask my peer about what I do not understand about } \\
\text { project work. }\end{array}$ & 3.92 & .793 \\
\hline 21- I can select the required resistor or capacitor for certain application. & 2.83 & 1.337 \\
\hline \multicolumn{3}{|l|}{ IV. Practical Skills in Electronics : } \\
\hline 22- I prefer soldering an electronic circuit instead of breadboard wiring. & 3.17 & 1.030 \\
\hline 23- I enjoy troubleshooting electronic systems & 1.83 & .718 \\
\hline 24- Project work increases my interest in Electronic Courses & 3.42 & .669 \\
\hline 25- Project work helps me enhance the sense of responsibility & 4.00 & .853 \\
\hline $\begin{array}{l}\text { 26- Project work helps me use my creativity and enrich my practical } \\
\text { skills. }\end{array}$ & 3.33 & .778 \\
\hline 27- Projects encourage students to develop self assessment skills. & 3.08 & 1.165 \\
\hline $\begin{array}{l}\text { 28- Project work helps me to identify different types of transistors and } \\
\text { diodes. }\end{array}$ & 3.25 & .866 \\
\hline 29 I can easily use Op-Amps ICs to construct practical applications & 3.08 & .793 \\
\hline 30- Project work helps me enhance my self confidence as future engineer. & 4.00 & .603 \\
\hline
\end{tabular}

